\title{
Complete Absence of the Third Component of Complement in Man
}

\author{
M. Ballow, J. E. ShiRa, L. Harden, Soo Young Yang, and \\ Noorbibi K. DAY \\ From the Walter Reed Hospital, Washington, D. C. 20012, and Sloan-Kettering \\ Institute for Cancer Research, New York 10021
}

\begin{abstract}
A B S T R A C T A 4-yr-old female patient who has recurrent infections with encapsulated bacteria and gramnegative organisms was found to have a complete absence of total hemolytic complement and C3. Total hemolytic complement was reconstituted by the addition of functionally pure C3. With the exception of a moderately reduced hemolytic $\mathrm{C} 4$, all other $\mathrm{C}$ components, measured hemolytically and by radial immunodiffusion, were present in normal amounts. By Ouchterlony analysis, the patient's serum contained C3b inactivator and properdin but no antigenic C3. Activation of the alternate pathway was examined by purified cobra venom factor (CVF) and inulin. Neither of these substances led to activation of properdin factor $\mathrm{B}$ to $\overrightarrow{\mathrm{B}}$. On addition of partially purified Cordis $\mathrm{C} 3$, in four out of four instances and with different preparations of Cordis $\mathrm{C} 3$, activation of factor $\mathrm{B}$ to $\overline{\mathrm{B}}$ occurred in the inulin-serum- $\mathrm{C} 3$ mixture. In contrast, activation of factor $B$ to $\bar{B}$ occurred only once out of four times with CVF-serum-C3 mixtures. Immune adherence was found to be normal in the patient's serum and could be removed by anti-C4 antiserum or hydrazine treatment. A marked opsonic defect was present against Escherichia coli. Serum bactericidal activity against a rough strain of $E$. coli was also defective. The ability to mobilize an inflammatory response was examined by Rebuck skin window technique. A delay in neutrophil migration occurred until the 6 th $h$. In vitro lymphocyte transformation and serum immunoglobulins were normal. The proportion of peripheral blood $T$ cells forming spontaneous sheep erythrocyte rosettes and the per-
\end{abstract}

Dr. Day is an Established Investigator of the American Heart Association. Dr. Ballow's present address is: Department of Pediatrics, University of Connecticut Health Center, Farmington, Conn. 06032.

Received for publication 7 February 1975 and in revised form 12 May 1975.

The Journal of Clinical Investigation Volume 56 September 1975.703-710 centage of $\mathrm{B}$ cells forming EAC rosettes by the $\mathrm{C} 3$ receptor were normal. The significance of the absence of $\mathrm{C} 3$ in our patient is emphasized by the increased number of infections with encapsulated bacteria and the decreased functional biological activities of the $C$ system, important in host defense mechanism(s).

\section{INTRODUCTION}

The importance of the complement $(C)^{1}$ system to host defense and the development of tissue injury stems from the study of both congenital and acquired $\mathrm{C}$ deficiencies in man and in experimental animals (1). The pathogenesis of the clinical diseases associated with the acquired states of $\mathrm{C}$ deficiency is often a direct reflection of C-dependent biological effector mechanism(s) of inflammation. The pathogenesis of glomerular damage seen in many types of renal disease is a good example (2). On the other hand, study of the congenital $\mathrm{C}$ deficiencies has broadened our understanding of the role of $\mathrm{C}$ in disease states by examining the lack of effector mechanisms and control proteins. The absence of these control proteins or inhibitors in the $\mathrm{C}$ system has been clearly associated with specific clinical patterns of disease. Absence of $\mathrm{C} 1$ esterase inhibitor is seen in hereditary angioneurotic edema (3) and has been reported to be associated with renal disease in three cases $(4,5)$. Absence of $C 3 b$ inactivator is associated with increased susceptibility to infections (6). More recently an increased association of collagen vascular diseases with deficiencies of the early $\mathrm{C}$ components $\mathrm{C} 1 \mathrm{~s}$ (7), C1r (8-10), C2 (4, 11-15), and C4 (16), and of the later components C5 (17) and C7 (18) have been recognized. One patient with C6 defi-

${ }^{1}$ Abbreviations used in this paper: C, complement; CVF, cobra venom factor; IA, immune adherence; $P$, properdin. 
ciency (19) and one with C7 deficiency (20) are apparently healthy.

Deficiencies of C3 are of particular importance because $\mathrm{C} 3$ is situated at the pivotal point between the classical and alternate pathways. ${ }^{2}$ Only one such case of primary C3 deficiency has been reported in a patient with increased susceptibility to infection (21). In the present investigation, we report a complete absence of serum C3 in a young girl with problems of recurrent infections with encapsulated organisms. The biological functions of the $\mathrm{C}$ system that contribute to host defense and the activation of the alternate pathway in the absence of $\mathrm{C} 3$ are presented.

\section{CASE REPORT}

This $4 \frac{1}{4}$-yr-old white girl was well until 3 wk of age, when she developed persistent loose, watery stools. Several formula changes were made with no apparent benefit. However, the child continued to grow along the 3rd percentile. During the 1st yr of life, she had repeated episodes of otitis media that responded slowly to ampicillin each time. At 20 mo of age myringotomy tubes were placed for drainage. Cultures grew Haemophilus influenzae type B.

At 17 and 23 mo of age, the patient had febrile illnesses associated with the growth of Diplococcus pneumoniae from the nose and blood. The patient to date has not had pneumonia or meningitis.

At $20 \mathrm{mo}$ of age she was evaluated for persistent loose stools and recurrent otitis media. $\mathrm{X}$ rays of the gastrointestinal system, malabsorption studies, multiple bacterial cultures, and examinations of the stool for ova and parasites were all negative. Special studies included a splenic scan and nitroblue tetrazolium reduction tests, which were normal. Appropriate elevation of the peripheral polymorphonuclear leukocyte count occurred with infection. Quantitative immunoglobulins and in vitro tests for cellular immunity were normal at this time. She was placed on a milk-free, gluten-free diet and prophylactic penicillin. At $3 \mathrm{yr}$ of age, the diet and penicillin were discontinued. Her weight remained in the 28th percentile, and bowel function was no longer a problem. Tests for anti-DNA and antinuclear antibodies were negative. However, after prophylactic antibiotics were discontinued, she began to have episodes of recurrent infections of the urinary tract with $E$. coli organisms. This necessitated placing the patient once again on long-term antibiotics and to date she has done well.

${ }^{2}$ Terms used in this paper with synonyms used by other investigators: alternate pathway, alternative or properdin pathway; properdin factor $\mathrm{B}, \mathrm{C} 3$ proactivator; properdin factor D, C3 proactivator convertase.

\section{METHODS}

Buffers and assays of $\mathrm{C}$ and $\mathrm{C}$ components $\mathrm{C} 1-\mathrm{C} 9$ have been described elsewhere $(10,12)$. Reconstitution of total hemolytic complement in deficient serum was achieved as follows: To $0.1 \mathrm{ml}$ of serum, $0.3 \mathrm{ml}$ of functionally pure Cordis C3 $\left(1,000 \mathrm{CH}_{50}\right.$ units $\left./ \mathrm{ml}\right)$ and $0.6 \mathrm{ml}$ of buffer was added. Functional properdin factor $B$ was assayed according to previously described methods using indirect lysis of glutathione-treated cells and purified cobra venom factor (CVF) (22). Immune adherence was performed according to the method of Nishioka (23). Purified CVF was prepared according to the method of Ballow and Cochrane (24).

Immunochemical determinations of $\mathrm{Clq}, \mathrm{C} 3, \mathrm{C} 4$, and factor B were carried out by the Mancini, Carbonara, and Heremans technique (25). C1q antiserum was prepared according to the method of Hanauer and Christian (26); anti-C4 antiserum was purchased from Hyland Div., Travenol Laboratories, Inc., (Costa Mesa, Calif.); and antifactor B antiserum was prepared according to the method of Götze and Müller-Eberhard (27). Anti-C3 antiserum was prepared as described before (28).

Properdin (P), C3b inactivator, and antigenic C3 were analyzed by the Ouchterlony double-immunodiffusion method. Antiserum to C3b inactivator was kindly supplied by Dr. Peter Lachmann. Properdin was purified according to previously described methods (29). The isolated properdin had a slight IgG contaminant. This IgG was removed by immunoadsorbent column containing charged anti-IgG antibody (30), by well-defined methods. Rabbits were immunized with the treated properdin and the antiserum obtained gave a monospecific band when tested by immunoelectrophoresis against whole human serum.

The alternate pathway was examined by incubating the patient's serum either with inulin $(100 \mathrm{mg} / \mathrm{ml})$ or purified $\mathrm{CVF}$ at $37^{\circ} \mathrm{C}$ for $1 \mathrm{~h}$ (27). Partially purified C3 (Cordis Laboratories, Miami, Fla.) $\left(1,000 \mathrm{CH}_{50} \mathrm{U} / \mathrm{ml}\right)$, was used to reconstitute the patient's serum. Activation of factor $B$ to $\overline{\mathrm{B}}$ was examined by immunoelectrophoresis with monospecific antisera to factor $B$.

Serum bactericidal assay was performed as described previously (31). Phagocytic studies with the patients serum and normal human neutrophils were kindly performed by Dr. E. Grimes, using coagulase positive Staphylococcus aureus (strain 5201) and a fresh isolate of $E$. coli by the method of Maalфe (32). The percent of phagocytosis was calculated as follows :

(number of original bacteria - number of surviving bacteria)/number of original bacteria $\times 100$.

Serum immunoglobulins were quantified on Hyland plates. Lymphocyte transformation tests were performed by a micro method in which $2 \times 10^{5}$ lymphocytes $(0.2 \mathrm{ml})$, separated by Ficoll-Hypaque gradient centrifugation, were cultured in Micro Test II plates (Falcon Plastics, division of BioQuest, Oxnard, Calif.) with either mitogen or specific antigen $(0.025 \mathrm{ml})$. RPMI 1640 medium, supplemented with antibiotics, heparin, L-glutamine, HEPES buffer, and $15 \%$ pooled human serum was used to support the cultures.

Triplicate cultures with unstimulated cultures as controls were incubated at $37^{\circ} \mathrm{C}$ in an incubator containing $5 \% \mathrm{CO}_{2}$ as follows: mitogens, $72 \mathrm{~h}$; mixed lymphocyte cultures, 5 days; specific antigens, 6 days. $18 \mathrm{~h}$ before harvesting, cultures were labeled with [methyl- ${ }^{3} \mathrm{H}$ ] thymidine, $0.5 \mu \mathrm{Ci}$. $\quad(2.0 \mathrm{Ci} / \mathrm{mM}$, New England Nuclear, Boston, 
TABLE I

Complement Components Determined by Hemolytic Assays in Fresh Serum of a Patient with C3 Deficiency*

\begin{tabular}{llllllllll}
\hline $\mathrm{C} 1$ & $\mathrm{C} 2$ & $\mathrm{C} 3$ & $\mathrm{C} 4$ & $\mathrm{C} 5$ & $\mathrm{C} 6$ & $\mathrm{C} 7$ & $\mathrm{C} 8$ & $\mathrm{C} 9$ & $\mathrm{~B} \ddagger$ \\
92 & 83 & 10 & $52 \S$ & 84 & 115 & 103 & 140 & 77 & $44 \|$ \\
\hline
\end{tabular}

Immunochemical Determination by Mancini Technique

\begin{tabular}{cccc}
\hline & $\mathrm{Clq}$ & $\mathrm{B}$ & $\mathrm{C} 4$ \\
\hline & $\mu g N / m l$ & $\mu g / m l$ & $m g / 100 \mathrm{ml}$ \\
Patient & 20.4 & 270 & $17.7 \S$ \\
Normal & $17-20$ & $173-247$ & $25-37$ \\
\hline
\end{tabular}

* Results are expressed as percent of normal values. Normal values for hemolytic titers for $\mathrm{C}$ components have been described elsewhere (10).

$\ddagger$ Functional assay of properdin B (expressed as CH50 hemolytic $U$ ) by indirect lysis of glutathione-treated cells of CVF-treated serum (22). Normal range of 40 healthy adults: $104-150 \mathrm{CH}_{50} \mathrm{U} / \mathrm{ml}$.

$\S$ Below 1 SD.

|| Below 2 SD.

Mass.). The incorporation of $\left[\mathrm{H}^{3}\right]$ thymidine was determined by liquid scintillation spectrophotometry.

$T$ and $B$ cell rosette formation were tested by the techniques of Jondal and Klein (33) with minor modifications.

The Rebuck skin window test was carried out by previously described methods (34). Inflammation was induced by abrasion of the epidermis, and duplicate windows placed on the volar surface of the forearm and upper back.

\section{RESULTS}

Table I represents the results of $\mathrm{C}$ components of the patient's serum measured immunochemically and by functional assays. C1q and factor B were present in normal amounts, whereas the $\mathrm{C} 4$ concentration was slightly reduced immunochemically (Table I). C3 was totally absent, as was the total hemolytic $\mathrm{C}$ activity. The absence of $\mathrm{C} 3$ was confirmed by Ouchterlony analysis. The precipitin line obtained between normal hu-

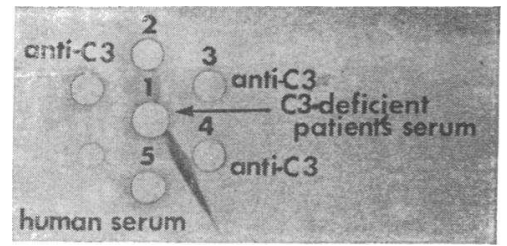

FIGURE 1 Ouchterlony pattern of C3-deficient patient's serum and normal human serum containing monospecific antiserum against purified human C3. 1, contains patient's serum; $2,3,4$, contain anti-C3 antiserum; 5 , contains normal human serum; A reaction occurred between wells 4 and 5. As shown, the precipitin band entered the well containing the patient's serum.

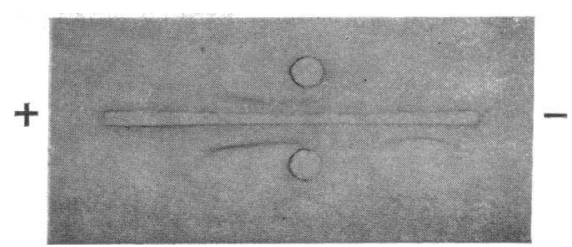

FIGURE 2 Immunoelectrophoretic pattern of patient's serum after treatment with inulin by the method of Götze and Müller-Eberhard (27), using 2\% agar, barbital buffer, $\mathrm{pH}$ 8.5, ionic strength 0.05 , containing $0.01 \mathrm{M}$ EDTA, and a potential gradient of $6 \mathrm{~V} / \mathrm{cm}$ for $2 \frac{1}{2} \mathrm{~h}$ at $10^{\circ} \mathrm{C}$. $50 \mu \mathrm{l}$ normal human serum (lower well) were incubated with $5 \mu 1$ of a $100 \mathrm{mg} / \mathrm{ml}$ inulin suspension. Center trough contains monospecific antiserum against factor B. Conversion of $\mathrm{B}$ occurred only in normal human serum.

man serum and antisera to C3 went directly into the center well containing the patient's serum (Fig. 1). The remaining components $\mathrm{C} 1, \mathrm{C} 2, \mathrm{C} 5, \mathrm{C} 6, \mathrm{C} 7$, and $\mathrm{C} 8$ and $\mathrm{C} 9$, assayed functionally, were all normal with the exception of hemolytic $\mathrm{C} 4$, which was moderately reduced (Table I). Properdin factor $B$ measured functionally was $44 \%$ of a pool of normal human serum (normal range 104-150).

To rule out the presence of an inhibitor to $C 3$, functionally pure Cordis C3 was added to deficient serum (final dilution of $300 \mathrm{CH}_{50} \mathrm{U} / \mathrm{ml}$ ). Total hemolytic $\mathrm{C}$ was restored by $55 \%$ of normal values (normal range $95 \pm 13 \mathrm{CH}_{80} \mathrm{U} / \mathrm{ml}$ ), suggesting that the unmeasurable C3 was not due to the presence of an inhibitor in our patient's serum. The electrophoretic mobility of $\mathrm{P}$ was the same as for normal serum. C3b inactivator was present by Ouchterlony analysis.

The functional integrity of the alternate pathway was tested by incubating the patient's serum with inulin or CVF. No conversion of factor $\mathrm{B}$ to $\overline{\mathrm{B}}$ was observed with either inulin or CVF (Figs. 2 and 3 ). However, on addition of partially purified Cordis C3 to mixtures of the patient's serum and inulin, or patient's serum and CVF, a conversion of factor $B$ to $\bar{B}$ was observed on four out of four occasions in the presence of inulin (Fig. 4) but only once out of four times in the presence

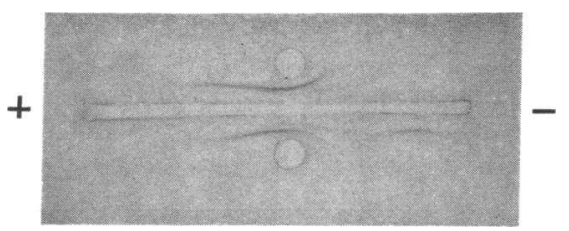

FIGURE 3 Immunoelectrophoretic pattern of patient's serum after treatment with purified CVF (Naja naje). The conditions for electrophoresis are described in Fig. 1. Upper well contains patient's serum and CVF ( $50 \mu 1$ of serum and $5 \mu 1$ of CVF) and lower well contains normal human serum in the same concentrations as above. Conversion of $B$ occurred only in normal human serum. 


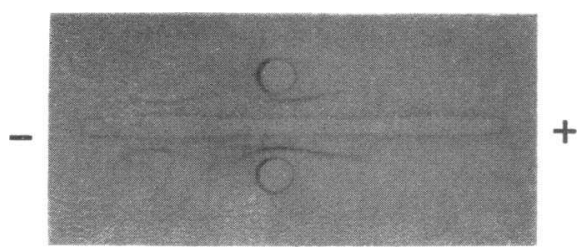

Figure 4 Immunoelectrophoretic pattern of patient's serum (upper well) containing $5 \mu \mathrm{l}$ inulin and $20 \mu \mathrm{l}$ Cordis C3 $(1,000 \mathrm{CH} 50 \mathrm{U} / \mathrm{ml})$ and normal human serum containing $5 \mu \mathrm{l}$ inulin and $20 \mu \mathrm{l}$ barbital buffer. Conversion of factor B occurred with patient's serum and normal human serum in four out of four instances with different batches of Cordis C3. In contrast, only in one of four instances conversion of B was observed when the patient's serum was treated with CVF and Cordis C3, even when the CVF concentration was varied from 2 to $50 \mu \mathrm{g} / \mathrm{ml}$ or when CVF was kept constant and Cordis C 3 was varied.

of CVF. Each time a different preparation of Cordis $\mathrm{C} 3$ was used.

Since serum opsonization and immune adherence (IA) require $\mathrm{C} 3$, these functions were tested. The IA titer of the patient's serum was the same as normal human serum $(3,200)$ (Table II). This was repeated several times and the IA titre was always within one tube dilution of normal human serum. Since the patient's serum does not contain C3, C4-dependent IA was examined. The patient's serum was treated with hydrazine $(0.015 \mathrm{M})$ or antisera to human $\mathrm{C} 4$. Both procedures either abolished or markedly reduced IA titers (Table II).

Serum bactericidal activity was highly defective when compared with normal human serum $(10.9 \%$ of normal serum). Addition of purified C3 reconstituted the bactericidal activity to $52.5 \%$ of normal serum (Table III). Opsonic activity in the patient's serum was studied with polymorphonuclear leukocytes from normal adults. The phagocytosis of Staphylococcus aureus (Fig. 5) in $2 \mathrm{~h}$

TABLE II

Immune Adherence Levels of C3-Deficient Serum and Normal Human Serum*

\begin{tabular}{lr}
\hline NHS $\ddagger$ & 3,200 \\
Patient's serum & 3,200 \\
Hydrazine-treated NHS§ & 200 \\
Hydrazine-treated patient & 0 \\
NHS-anti C4\| & 1,600 \\
Patient-anti C4 & 0 \\
\hline
\end{tabular}

* Expressed as reciprocal of the titre.

$\ddagger$ Normal human serum.

$\S 0.015 \mathrm{M}$ hydrazine (final concn) incubated with patient's/ NHS serum at $37^{\circ} \mathrm{C}$ for $45 \mathrm{~min}$ and dialyzed against veronal buffer overnight.

\| Equal volumes of patient's/NHS serum and antisera to $\mathrm{C} 4$, incubated $37^{\circ} \mathrm{C}$ for $30 \mathrm{~min}$ and overnight at $0^{\circ} \mathrm{C}$.
TABLE III

Bactericidal Activity of C3-Deficient Patient's Serum Compared with Normal Human Serum

\begin{tabular}{lcc}
\hline & $\begin{array}{c}\text { Amt. of } \\
\text { serum }\end{array}$ & $\begin{array}{c}\text { Percent of } \\
\text { normal }\end{array}$ \\
\hline Normal human serum & $m l$ & $\%$ \\
C3-deficient serum & 0.0084 & 100 \\
C3-deficient serum + Cordis C3 & 0.0770 & 10.9 \\
\hline
\end{tabular}

Bactericidal activity against a rough strain of $\mathrm{E}$. coli was tested according to the method of Muschel and Treffers (31). The results are expressed as the amount of serum necessary to kill $50 \%$ of the bacteria. The bactericidal activity of the patient's serum was $10.9 \%$ of normal. On reconstitution of the patient's serum with 1,000 hemolytic $\mathrm{U} / \mathrm{ml}$ of Cordis $\mathrm{C} 3$, serum bactericidal activity was $52.5 \%$ of normal serum.

was only slightly reduced with the patient's serum (81\%) compared to control serum (96\%). In contrast, marked impairment of opsonic activity ( $>90 \%$ ) was demonstrated with the patient's serum when $E$. coli organism was used in the phagocytic assay (Fig. 6).

The capacity of the patient to mobilize neutrophils in an inflammatory lesion was examined by the $\mathrm{Re}-$ buck skin window. At 2 and $4 \mathrm{~h}$, virtually no inflammatory cells were seen. In normal children (4-8 yr of age) at $2 \mathrm{~h}$, neutrophils start to mobilize into the area of inflammation with many neutrophils present at 3-4 h.

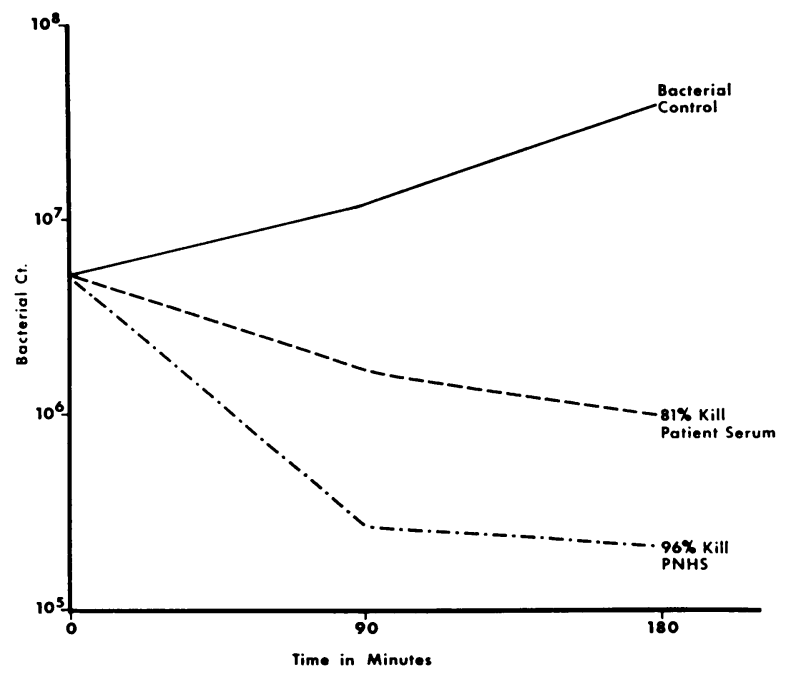

Figure 5 Phagocytic function of the patient's serum ( $\mathrm{Pt}$ serum) (---), compared with pooled normal human serum $(\cdot-\cdot)$. Phagocytic function of the patient's serum was only slightly reduced $(81 \%)$, compared with $96 \%$ phagocytic function of normal serum for Staphylococcus aureus 5201. The percent phagocytic function was calculated as follows: [ (number of original bacteria - number of surviving bacteria)/number of original bacteria] $\times 100$. 


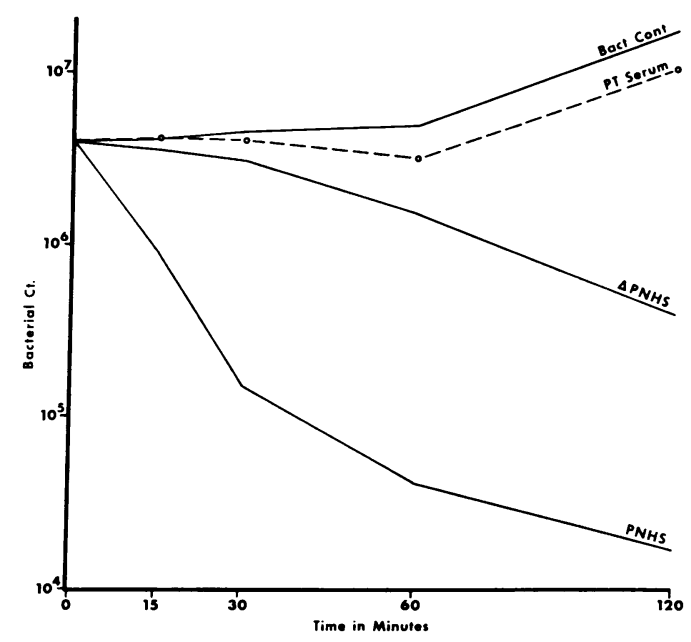

FIGURE 6 Phagocytic function of the patient's serum ( $\mathrm{Pt}$ serum) (-.-.-), compared with pooled normal human serum (PNHS) (-) and heated $\left(56^{\circ} \mathrm{C}, 30 \mathrm{~min}\right)$ PNHS. The patient's serum was severely impaired in phagocytic function by over $90 \%$ when compared with the phagocytic function of normal human serum for $E$. coli.

Subsequently, at 6 and $8 \mathrm{~h}$ an inflammatory infiltrate of neutrophils developed with the appropriate shift to a mononuclear cell response in our patient.

Quantitative serum immunoglobulins were normal for the patient's age: IgG, $430 \mathrm{mg} / 100 \mathrm{ml}$; IgM, 135 $\mathrm{mg} / 100 \mathrm{ml}$; $\operatorname{IgA}, 67 \mathrm{mg} / 100 \mathrm{ml}$; and $\mathrm{IgE}, 60 \mathrm{IU}$. In vitro lymphocyte proliferation to phytohemagglutinin, allogeneic cells in mixed lymphocyte culture, and to specific antigen (streptokinase/streptodornase) were normal.

Quantitation of the peripheral blood $\mathrm{T}$ cells by sheep red blood cell rosetting technique was 64\% (normal $61 \pm 3.8 \%$ ). B-cell quantitation by rosette formation with the C3 receptor (EAC) was normal (18\%).

\section{DISCUSSION}

Deficiency of C3 has been reported in only one other patient by Alper et al. (21). Their patient had many problems with infections by pyogenic organisms. We present an additional girl with C3 deficiency. No other family members are available for genetic studies because the child was adopted. Of particular interest was that the bacterial infections in our patient were primarily with encapsulated organisms such as Haemophilus infuenzae and Diplococcus pneumoniae. Since resistance to the early stages of infection with encapsulated organisms may be related to the alternate pathway $(35,36)$, examination of the biological functions related to the $\mathrm{C}$ amplification systems were studied.

The IA reactivity of the patien ‘'s serum was normal. This phenomenon is based on the ability of antigenantibody complement complexes to adhere to nonsensi- tized cells such as red cells, leukocytes, macrophages, and platelets (37). Early studies demonstrated that IA depended on bound C3 (37). Nelson emphasized that IA was important in the opsonization of viruses and bacteria in the mechanism of phagocytosis (38). However, our patient has no C3. Recent studies by Cooper have demonstrated that bound $\mathrm{C} 4$ can produce IA indistinguishable from C3-dependent IA (39). The reactivity of $\mathrm{C} 4$ in our patient in IA was lost after treatment of the patient's serum with hydrazine or antiserum to $\mathrm{C} 4$. This $\mathrm{C} 4$-dependent IA reactivity may be important in enhancing in vivo opsonization and phagocytic mechanisms.

When the patient's serum was examined for its ability to support the phagocytosis of two bacterial organisms, i.e. Staphylococcus aureus and a freshly isolated strain of $E$. coli, a marked deficiency in opsonic activity against only the $E$. coli organism was observed. This is consistent with the child's clinical problems with encapsulated bacteria and gram-negative organisms. These bacterial organisms are primarily handled by the alternate pathway, especially if specific antibodies are not present (40). Thus, phagocytosis will be significantly compromised in the absence of C3. On the other hand, if specific antibodies are present, as is often the case for Staphylococcus aureus, phagocytosis may proceed by the classical pathway in which C4-dependent IA may play a role. The in vitro opsonization studies of the Staphylococcus organism and the lack of infections clinically with gram-positive, nonencapsulated organisms such as Staphylococcus or Streptococcus suggest that the C4-dependent IA mechanism may be operating in our patient.

Another important aspect of the C-related inflammatory response is the production of chemotactic factor $(\mathrm{s})$. This was indirectly examined in vivo by the Rebuck skin window technique with abrasion as the inciting inflammatory stimulus (34). There was an early impairment of the mobilization of neutrophils. An inflammatory cellular response developed subsequently at 6 and $8 \mathrm{~h}$. The absence of C3 may have contributed to the early impairment of neutrophil mobilization, overcome as other leukotactic substances were generated $(41,42)$. Our patient does, however, develop an appropriate leukocytosis during her infections, in contrast to the other reported patient with C3 deficiency described by Alper et al. (21). Alper's patient failed to have a neutrophilia even with severe infections, although her neutrophils showed normal chemotaxis in response to hydrolysed casein. A Rebuck skin window was not done, nor was the generation of chemotactic activity from their patient's serum tested.

Hemolytic total $\mathrm{C}$ as well as bactericidal activity against $E$. coli organisms was restored by the addition 
of functionally pure C3. These observations suggest that the failure to measure hemolytic $\mathrm{C} 3$ is not due to the presence of an inhibitor to C3.

The functional integrity of the alternate pathway was examined by the indirect lysis of glutathione-treated sheep erythrocytes by CVF (22), and by the cleavage of factor $B$ to $\bar{B}$ with inulin and CVF. When cleavage of factor $B$ was examined by activation with inulin or CVF, no electrophoretic conversion of factor B occurred. With the addition of partially purified Cordis $\mathrm{C} 3$ to the inulin-serum mixture, conversion of factor $\mathrm{B}$ to $\overline{\mathrm{B}}$ occurred in all four instances with different preparations of Cordis C3. These observations were similar to those described by Alper et al. in their C3deficient serum. A conversion of factor B with zymosan occurred only after reconstitution of the patient's serum with purified C3 (21).

In contrast, with the addition of Cordis $\mathrm{C} 3$ to the patient's CVF-serum mixture, cleavage of factor $\mathrm{B}$ to $\overline{\mathrm{B}}$ occurred only with one lot of Cordis C3 and not with three other preparations. Furthermore, when the concentration of CVF was varied from 2 to $50 \mu \mathrm{g} / \mathrm{ml}$, with constant amounts of $\mathrm{C} 3$ or when the amount of C3 was varied with two different concentrations of CVF, 5 and $25 \mu \mathrm{g} / \mathrm{ml}$, conversion of factor $\mathrm{B}$ to $\overline{\mathrm{B}}$ was still not observed. It has been shown that $\mathrm{C} 3 \mathrm{~b}$ is not needed for the conversion of factor B by CVF (43). In fact, $\mathrm{C} 3 \mathrm{~b}$ is analogous to $\mathrm{CVF}$ in its requirement for factors $B$ and $\bar{D}$ in the conversion of factor $B$ and the generation of C3-cleaving activity $(44,45)$.

Fearon, Austen, and Ruddy (45) have recently demonstrated that factor $\mathrm{D}$ exists in a precursor state in serum and that this form of factor $D$ is inactive in $\mathrm{CVF}$-induced conversion of factor $\mathrm{B}$. The conversion of factor B by CVF essentially bypasses the early components of the alternate pathway, but requires active factor $D(\bar{D})$ for the cleavage of factor $B$. On the other hand, inulin or zymosan activates the early components of the alternate pathway, in which activated $P(\bar{P})$ in the presence of C3 (46) activates factor $\mathrm{D}$ to $\overline{\mathrm{D}}(46)$. Since CVF does not lead to the activation of $\mathrm{P}$, no change in the state of factor $\mathrm{D}$ can be expected even in the presence of $\mathrm{C} 3$. Since our patient lacks C3, the possibility exists that all the factor D in the patient's serum is in the precursor form, and thus inactive for the CVF-induced conversion of factor B. The demonstration of cleavage of factor $B$ with one Cordis C3 preparation could be attributed to a small amount of active factor $\mathrm{D}$ in the preparation.

Other explanations for the failure of $\mathrm{CVF}$ to cleave factor B are possible. Although no electrophoretic conversion of factor $B$ by $C V F$ could be demonstrated, functional factor $\mathrm{B}$ activity by $\mathrm{CVF}$-induced indirect lysis of glutathione-treated cells was demonstrated.
The discrepancy between the normal serum concentrations of factor $\mathrm{B}$ measured immunochemically and the reduced functional factor $B$ activity ( $44 \%$ of normal pooled serum) may be related this failure of CVF to convert factor B. Recently, Day and Müller-Eberhard (47) reported that a cold-dependent activation of the alternate pathway occurred without conversion of factor $B$, suggesting that enzymatically active factor $B(\bar{B})$ can exist without cleavage. Finally, our patient may lack another serum protein, i.e., cobra venom-binding protein $(48,49)$, important as a co-factor in the CVF-induced cleavage of factor $B$ to $\bar{B}$ and in the indirect lysis of glutathione-treated erythrocytes.

\section{ACKNOWLEDGMENTS}

The authors would like to thank Dr. E. Grimes (SloanKettering Institute) for performing the phagocytic assays and Miss Virginia Battista (Walter Reed Hospital) and Miss Sylvia Pryce (Sloan-Kettering Institute) for their invaluable technical assistance.

\section{REFERENCES}

1. Lachmann, P. J. 1972. Genetic deficiencies of the complement system. In Ontogeny of Acquired Immunity. R. Porter and J. Knight, editors. Associated Scientific Publishers, Amsterdam. 193-208.

2. Cochrane, C. G., and D. Koffler. 1973. Immune complex disease in experimental animals and man. $A d v$. Immunol. 16: 185-264.

3. Donaldson, V. H., and R. R. Evans. 1963. A biochemical abnormality in hereditary angioneurotic edema. Absence of serum inhibitor of $\mathrm{C}^{\prime} 1$ esterase. Am. J. Med. $35: 37-44$.

4. Pickering, R. J. A. F. Michael, Jr., R. C. Herdman, R. A. Good, and H. Gewurz. 1971. The complement system in chronic glomerulonephritis: three newly associated aberrations. J. Pediatr. 78: 30-43.

5. Kohler, P. F., J. Percy, W. M. Campion, and C. J. Smyth. 1974. Hereditary angioedema and "familial" lupus erythematosus in identical twin boys. $A m . J$. Med. 56: 406-411.

6. Abramson, N., C. A. Alper, P. J. Lachmann, F. S. Rosen, and J. H. Jandl. 1971. Deficiency of C3 inactivator in man. J. Immunol. 107: 19-27.

7. Pondman, K. W., J. W. Stoop, R. H. Cormane, and A. J. Hannema. 1968. Abnormal $C^{\prime} 1$ in a patient with systemic lupus erythematosus. J. Immunol. 101: 811. (Abstr.)

8. Pickering, R. J., G. B. Naff, R. M. Stroud, R. A. Good, and H. Gewurz. 1970. Deficiency of $\mathrm{C} 1 \mathrm{r}$ in human serum. Effects of the structure and function of macromolecular C1. J. Exp. Med. 131: 803-815.

9. Moncada, B., N. K. B. Day, R. A. Good, and D. B. Windhorst. 1972. Lupus-erythematosus-like syndrome with familial defect of complement. N. Engl. J. Med. 286: 689-693.

10. Day, N. K., H. Geiger, R. Stroud, M. deBracco, B. Moncado, D. Windhorst, and R. A. Good. 1972. C1r deficiency: an inborn error associated with cutaneous and renal disease. J. Clin. Invest. 51: 1102-1108. 
11. Agnello, V., M. M. E. de Bracco, and H. G. Kunkel. 1972. Hereditary C2 deficiency with some manifestations of systemic lupus erythematosus. J. Immunol. 108: $837-840$.

12. Day, N. K., H. Geiger, R. McLean, A. Michael, and R. A. Good. 1973. C2 deficiency. Development of lupus erythematosus. J. Clin. Invest. 52: 1601-1607.

13. Sussman, M., J. H. Jones, J. D. Almeida, and P. J. Lachmann. 1973. Deficiency of the second component of complement associated with anaphylactoid purpura and presence of mycoplasma in the serum. Clin. Exp. Immunol. 14: 531-539.

14. Leddy, J. P., R. C. Klemperer, and M. M. Frank. 1975. Hereditary complement (C2) deficiency with dermatomyositis. Am. J. Med. 58: 83-91.

15. Wild, J., N. Zvaifler, H. J. Müller-Eberhard, and C. Wilson. 1974. Deficiency of the second component of complement (C2) in a patient with discoid lupus erythematosus (DLE). J.Clin. Invest. 53: 84a. (Abstr.)

16. Hauptman, G., E. Grosshans, and E. Heid. 1974. Systemic lupus erythematosus and hereditary complement deficiencies. A case with total C4 deficiency. Ann. Dermatol. Syphiligr. 101 : 479-496.

17. Rosenfeld, S. I., and J. P. Leddy. 1974. Hereditary deficiency of the fifth component of complement (C5) in man. J. Clin. Invest. 53: 67a. (Abstr.)

18. Boyer, J. T. 1974. Genetic defects of complement. In Progress in Immunology II, Vol. 1. L. Brent and J. Bolborow, editors. North Holland Publishing Co., Amsterdam. 288-290.

19. Leddy, J. P., M. M. Frank, T. Gaithert, J. Baum, and M. R. Klemperer. 1974. Hereditary deficiency of the sixth component of complement in man. I. Immunochemical, biologic, and family studies. J. Clin. Invest. 53: 544-553.

20. Wellek, B., and W. Opferkuch. 1974. A naturally occurring C7-inactivator in a case of C7-deficiency in man and in normal human serum. Fed. Proc. 33: 648. (Abstr.)

21. Alper, C. A., H. R. Colten, F. S. Rosen, A. R. Rabson, G. M. Macnab, and J. S. S. Gear. 1972. Homozygous deficiency of $\mathrm{C} 3$ in a patient with repeated infections. Lancet. 2 : 1179-1181.

22. Götze, O., and H. J. Müller-Eberhard. 1972. Paroxysmal nocturnal hemoglobinuria. Hemolysis initiated by the C3 activator system. N. Engl. J. Med. 286: 180-184.

23. Nishioka, K. 1963. Measurements of complement by agglutination of human erythrocytes reacting in immuneadherence. J. Immunol. 90: 86-97.

24. Ballow, M., and C. G. Cochrane. 1969. Two anticomplementary factors in cobra venom: hemolysis of guinea pig erythrocytes by one of them. J. Immunol. 103: 944 952.

25. Mancini, J., A. O. Carbonara, and J. F. Heremans. 1967. Immunochemical quantitation of antigens by single radial immunodiffusion. Immunochemistry. 2: 235-254.

26. Hanauer, L. B., and C. L. Christian. 1967. Clinical studies of hemolytic complement and 11 s component. Am. J. Med. 42: 882-890.

27. Götze, O., and H. J. Müller-Eberhard. 1971. The C3activator system: an alternate pathway of complement activation. J. Exp. Med. 134: 90s-108s.
28. Nilsson, U. R., and H. J. Müller-Eberhard. 1965. Isolation of $\beta_{1 w}$-globulin from human serum and its characterization as the fifth component of complement. $J$. Exp. Med. 122 : 277-298.

29. Pillemer, L., L. Blum, I. H. Lepow, O. A. Ross, E. W. Todd, and A. C. Wardlaw. 1954. The properdin system and immunity. I. Demonstration and isolation of a new serum protein, properdin, and its role in immune phenomenon. Science (Wash. D. C.). 120: .279-285.

30. Frommel, D., J. M. Dupuy, G. W. Litman, and R. A. Good. 1970. Use of immunoadsorbent techniques in the preparation of chemical agammaglobulinemia. J. Immunol. 105 : 1292-1295.

31. Muschel, L. H., and H. P. Treffers. 1956. Quantitative studies on the bactericidal actions of serum and complement. I. A. rapid photometric growth assay for bactericidal activity. J. Immunol. 76: 1-10.

32. Maaløe, O. 1946. On the relation between alexin and opsonin. Doctoral thesis. Munksgaard, A/S, Copenhagen.

33. Jondal, M., and G. Klein. 1973. Surface markers on human B and T lymphocytes. II. Presence of EpsteinBarr virus receptors on $\beta$ lymphocytes. J. Exp. Med. 138: $1365-1378$.

34. Rebuck, J. W., and J. H. Crowley. 1955. A method of studying leukocytic function in vivo. Ann. N.Y. Acad. Sci. 59: 757-805.

35. Winkelstein, J. A., H. S. Shin, and W. B. Wood, Jr. 1972. Heat labile opsonins to pneumococcus. III. The participation of immunoglobulin and of the alternate pathway of C3 activation. J. Immunol. 108: 1681-1689.

36. Jasin, H. E. 1972. Human heat labile opsonins: Evidence for their mediation via the alternate pathway of complement activation. J. Immunol. 109: 26-31.

37. Nelson, R. A. Jr. 1953. The immune-adherence phenomena. An immunologically specific reaction between microorganisms and erythrocytes leading to enhanced phagocytosis. Science (Wash. D. C.). 118: 733-737.

38. Nelson, D. S. 1963. Immune adherence. Adv. Immunol. 3: $131-180$.

39. Cooper, N. R. 1969. Immune adherence by the fourth component of complement. Science (Wash. D. C.). 165: 396-398.

40. Winkelstein, J. A. 1973. Opsonins: their function, identity, and clinical significance. J. Pediatr. 82: 747753.

41. Ward, P. A. 1970. Neutrophil chemotactic factors and related clinical disorders. Arthritis Rheum. 13: 181-186.

42. Ward, P. A., C. G. Cochrane, and H. J. Müller-Eberhard. 1965. The role of serum complement in chemotaxis of leukocytes in vitro. J. Exp. Med. 122: 327-346 and plate 22 .

43. Fearon, D. T., K. F. Austen, and S. Ruddy. 1973. Serum proteins involved in decay and regeneration of cobra venom factor-dependent complement activation. J. Immunol. 111 : 1730-1736.

44. Müller-Eberhard, H. J., and O. Götze. 1972. C3 proactivator convertase and its mode of action. J. Exp. Med. 135 : 1003-1008.

45. Fearon, D. T., K. F. Austen, and S. Ruddy. 1974 Properdin factor D: Characterization of its active site and isolation of the precursor form. J. Exp. Med. 139: 355-366. 
46. Götze, O., and H. J. Müller-Eberhard. 1974. The role of properdin in the alternate pathway of complement activation. J. Exp. Med. 139: 44.

47. Day, N. K., and H. J. Müller-Eberhard. 1974. Colddependent activation of the alternate complement pathway. Fed. Proc. 33 : 775. (Abstr.)

48. Alper, C. A., I. Goodkofsky, and I. H. Lepow. 1973. The relationship of glycine-rich $\beta$ glycoprotein to factor
$B$ in the properdin system and to the cobra factorfinding protein of human serum. J. Exp. Med. 137: 424-437.

49. Hunsicker, L. G., S. Ruddy, and K. F. Austen. 1973. Alternate complement pathway: factors involved in cobra venom factor (CoVF) activation of the third component of complement (C3). J. Immunol. 110: 128138. 